\title{
Sex ratio and parental investment in Trypoxylon (Trypargilum) agamemnon Richards (Hymenoptera, Crabronidae)
}

\author{
Buschini, MLT. ${ }^{\mathrm{a}}$ and Bergamaschi, $A C B .^{\mathrm{b}}$ \\ aPrograma de Pós-Graduação em Biologia Evolutiva, Universidade Estadual do Centro-Oeste - UNICENTRO, \\ Rua Salvatore Renna, 875, Santa Cruz, CEP 85015-430, Guarapuava, PR, Brazil

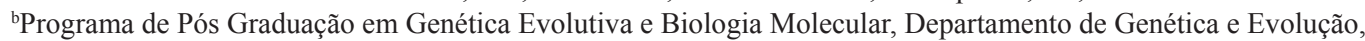 \\ Universidade Federal de São Carlos - UFSCar, CP 676, CEP 13565-905, São Carlos, SP, Brazil \\ *e-mail: isatunes@yahoo.com.br
}

Received: September 18, 2012 - Accepted: December 5, 2012 - Distributed: February 28, 2014

(With 3 figures)

\begin{abstract}
The life history and sex ratio data of the solitary wasp Trypoxylon agamemnon nesting in trap-nests in southern Brazil was recorded from January 2002 to December 2007. Its sex ratio is strongly female-biased, being bivoltine or multivoltine with until three generations per year. It has two alternative life histories (diapause and direct development) and overlapping generations. In addition to the conflict of interest between the sexes, it is possible that local mate competition occurs between males and may cause a greater investment in the production of females.
\end{abstract}

Keywords: Cabronidae, life-history, parental investment, sex ratio, mass-provisioning.

\section{Razão sexual e investimento parental em Trypoxylon (Trypargilum) agamemnon Richards (Hymenoptera, Crabronidae)}

\begin{abstract}
Resumo
Dados sobre a história de vida e a razão sexual da vespa solitária Trypoxylon agamemnon, que nidifica em ninhos-armadilha, foram registrado no sul do Brasil de janeiro de 2002 a dezembro de 2007. Sua razão sexual tendeu fortemente às fêmeas sendo bivoltina ou multivoltina, com até três gerações ao ano. Ela apresenta dois tipos de historia de vida (com diapausa e com desenvolvimento direto), e sobreposição de gerações. Além do conflito de interesses entre os sexos, é possível que a competição local por parceiros ocorra entre machos provocando um maior investimento na produção de fêmeas.
\end{abstract}

Palavras-chave: Cabronidae, história de vida, investimento parental, razão sexual, aprovisionamento massal.

\section{Introduction}

Hymenoptera are haplodiploid and females can determine the sex of each offspring by controlling the fertilization of the eggs (Flanders, 1965). This characteristic may have important fitness consequences because it allows the female to adjust the sex of individual offspring in response to environmental conditions (Molumby, 1997).

Oviposition of male and female eggs in response to environmental conditions can be viewed as a conditional strategy that affects the reproductive success of the female and that of each of her offspring (Charnov, 1979, 1982).

According to Fisher (1930), the total investment in sons and daughters should be equal because frequencydependent selection provides greater mating success for the rarer sex. Therefore, frequency-dependent selection favors the equal allocation of resources to sons and daughters. If sons and daughters are equally costly to produce, this equal investment produces equal numbers of males and females. However, if one sex is more costly to produce and if there is a disproportionate investment in the offspring of one

sex, then this difference will be corrected in subsequent generations by selection for parents that produce the sex that is in short supply.

Two important aspects of the distribution of parental investment involve brood size (Brockelman, 1975; Pianka, 1976) and sex ratios (Hamilton, 1967). For many massprovisioning wasps, the weight of provision per cell is a good predictor of each offspring's cost to the mother (Cowan, 1981; Frohlich and Tepedino, 1986), and body size of these insects is correlated with the amount of provisions in each cell (Brockmann and Grafen, 1989; Cowan, 1981). This amount may be influenced by such factors as hunting success, prey availability, species interactions and the size of the brood cell (Lin, 1979). The present study investigates parental investment in a mass-provisioning wasp, Trypoxylon (Trypargilum) agamemnon Richards, 1934, that uses spiders as food for its offspring (Buschini and Fajardo, 2010). For this purpose was analyzed its sex ratio, the weight of food consumed by the larvae and newly 
emerged adult weight. Furthermore, this paper provides additional information on its life history.

\section{Methods}

\subsection{Study areas}

The study was performed from January 2002 to December 2007 at Parque Municipal das Araucárias, with approximately 104 ha, located in the municipality of Guarapuava (PR), Brazil (2521'06” S, 51 28' 08” W, altitude $1,120 \mathrm{ml})$. The vegetation is composed of "Mixed Ombrophilous Forest" (42.75\%), gallery forest (10.09\%), fields (6.8\%), swamps (7.13\%) and altered areas (33.23\%) (Guarapuava, 2012).

According to the Köppen classification, the climate is humid mesothermic with no dry season and mild summers owing to the altitude. The winter is moderate with frequent occurrences of frost. The annual mean temperature is approximately 16 to $17.5{ }^{\circ} \mathrm{C}$ and rainfall is uniform throughout the year. The average monthly rainfall exceeds $100 \mathrm{~mm}$, and the annual rainfall averages $1961 \mathrm{~mm}$.

\subsection{Procedure}

The nests of T. agamemnon were obtained using trapnests made of $25 \times 20 \times 120 \mathrm{~mm}$ wooden blocks. The blocks were drilled longitudinally to a depth of $80 \mathrm{~mm}$ with apertures 7.0, 10.0, and $13.0 \mathrm{~mm}$ in diameter (Buschini, 2006). Before they were drilled, the wooden blocks were sawed in half longitudinally and then held together with adhesive tape to allow opening to examine the cavities.

Since T. agamemnon builds nests only in Araucaria forest (Buschini and Fajardo, 2010), the traps were placed only in an Araucaria forests fragment in this park. Two areas were studied in the fragment, with 2 transects (60 meters each) per area and 4 sampling stations per transect (20 meters apart). Twelve trap-nests, four with each opening diameter, were placed at each sampling station. Initially, 96 traps were used for sampling. Each trap was placed $1.5 \mathrm{~m}$ above the ground and inspected every two weeks. After January 2003, the trap-nests were inspected daily. From December 2003, four additional nests with a $5 \mathrm{~mm}$ aperture size were placed in the sampling stations. These additional nests brought the total for the study to
128 trap-nests. In each inspection, all completed nests were removed and immediately replaced with empty traps of the same diameter. The nests were then brought to the laboratory to investigate their contents.

\subsection{Data analyses}

The sex ratio was calculated as the ratio between the number of females and the number of males. A chisquared test was used to determine the extent to which the observed sex ratio deviated from the expected frequency (1 female:1 male) (Krebs, 1989). If eggs and/or larvae were present, the nest was closed to allow the completion of the life cycle and the emergence of the adults. Newly emerged adults were carefully removed and weighed (mg).

All the spiders from provisioned cells and that still contained an egg or nearly hatched larva, were weighed. This procedure enabled us to determine the relation between adult body size and the amount of food provided for males and females. Mann-Whitney and Kruskal-Wallis (Ayres et al., 2003) tests were used to test the hypotheses relating the body weight and the nest diameter, the body weight and the sex of the offspring, the sex of the offspring and the weight of provisions, and the premature development time and life history.

To obtain data on adult longevity and determine the existence of overlapping generations, between 2003 and 2007, all emerging wasps were individually marked with non-toxic ceramic paint and returned to their original habitat. Because the mark-recapture study resulted in no recaptures, estimates of longevity were based on the records of the last emergence of the adults in the laboratory and the last colonization in the field before the winter.

\section{Results}

\subsection{Life cycle}

During the six years of the study, we collected 654 nests of T. agamemnon which were built in Araucaria forest. The nests were built in the traps with smaller diameters, i.e., $5.0 \mathrm{~mm}(\mathrm{n}=364)$ and $7.0 \mathrm{~mm}(\mathrm{n}=290)$.

Trypoxylon agamemnon had two alternative life histories (Figure 1). The wasp may pupate immediately and emerge as an adult later in the same season (direct development)

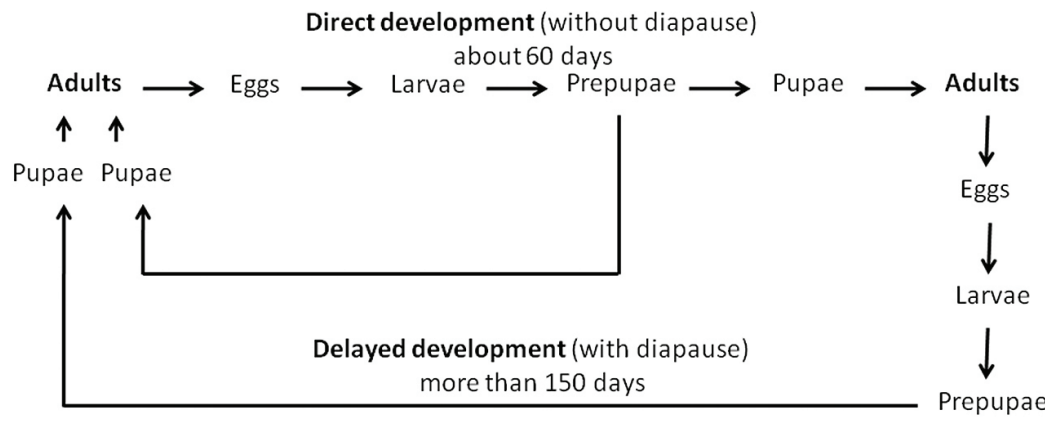

Figure 1. A schematic representation of the life cycle of T. agamemnon in southern Brazil. 
or many enter diapause, overwinter and pupate during the subsequent spring (delayed development).

The number of wasps with direct and delayed development varied widely among different months and years of sampling (Figure 2). During 2002 and 2003, some of the wasps from the nests collected in January and all of the wasps from the nests collected from February through May went into diapause (prepupae stage). These entered the adult phase beginning in September. In 2004 and 2006, T. agamemnon still exhibited direct development without diapause during January, but all the prepupaes went into diapause beginning in February and entered the adult phase beginning in September. In 2005, the prepupaes entered diapause later. They exhibited direct development in February and April. As in other years, they entered the adult phase beginning in September. The year 2007 was atypical. Individuals with direct development and individuals with delayed development both occurred during January and February and the adults emerged in August. The prepupaes remained in diapause only for a brief period.
Nesting also occurred during September 2002, May 2003, May 2006 and October 2007. Data for these nests are not included in Figure 2 because the prepupaes died and their sexes and life-cycle types could not be determined.

\subsection{Sex ratio}

The sex ratio was female-biased for all the years sampled. The sex ratios calculated for fixed values of aperture diameter were also significantly different from $1: 1$. These sex ratios were female-biased with the exception of the 5-mm diameter nests in 2006, in which the sex ratio was male-biased (Table 1).

We found that males and females were preferentially produced in the 5-mm and 7-mm diameter nests, respectively. Values for the sex ratio closer to 1:1 were found in the 5 -mm diameter nests in all of the years sampled (Table 1).

\subsection{Number of wasp generations per year}

During the six years of sampling, the average development time varied in direct development and in the wasps that spent the winter in diapause (Table 2). As

\section{$\triangle$ Female $1 \quad$ 曰 Male $1 \square$ Female $2 \square$ Male 2}

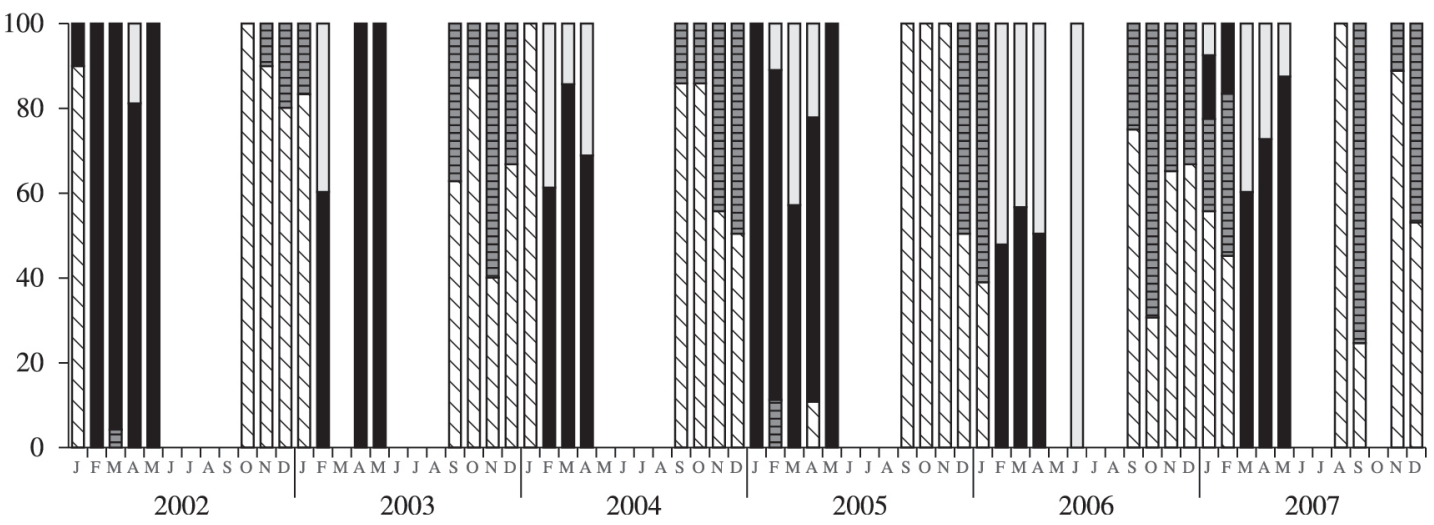

Figure 2. The percentages of T. agamemnon females (1) and males (1) developing directly and females (2) and males (2) overwintering over the season in 2002, 2003, 2004, 2005, 2006 and 2007.

Table 1. Numerical sex ratio of T. agamemnon obtained from 2002 to 2007 in two different trap-nest diameters and the total sex ratio.

\begin{tabular}{|c|c|c|c|}
\hline & $5 \mathrm{~mm}$ & $7 \mathrm{~mm}$ & TOTAL \\
\hline 2002 & $*$ & $\begin{array}{c}9.8+1 \text { 市 } 1 \text { } \\
(\chi 2=97.7 ; \mathrm{df}=1, \mathrm{P}<0.001)\end{array}$ & $\begin{array}{c}9.8 \text { 果: } 1 \text { ठ } \\
(\chi 2=97.7 ; \mathrm{df}=1, \mathrm{P}<0.001)\end{array}$ \\
\hline 2003 & $\begin{array}{c}2+: 1 \hat{\circ} \\
(\chi 2=82.9 ; \mathrm{df}=1, \mathrm{P}<0.001)\end{array}$ & $\begin{array}{c}2.7 \stackrel{+}{+} 10 \\
(\chi 2=26.12 ; \mathrm{df}=1, \mathrm{P}<0.001)\end{array}$ & $\begin{array}{c}2.6 \stackrel{+}{\circ}: 1 \hat{0} \\
(\chi 2=20.66 ; \mathrm{df}=1, \mathrm{P}<0.001)\end{array}$ \\
\hline 2004 & $\begin{array}{c}1.3 \stackrel{\circ}{ }: 10 \\
(\chi 2=45.14 ; \mathrm{df}=1, \mathrm{P}<0.001)\end{array}$ & $\begin{array}{c}5.1 \text { + } 10 \\
(\chi 2=33.94 ; \mathrm{df}=1, \mathrm{P}<0.001)\end{array}$ & $\begin{array}{c}2.8 \stackrel{9}{ }: 1 \AA \\
(\chi 2=19.08 ; \mathrm{df}=1, \mathrm{P}<0.001)\end{array}$ \\
\hline 2005 & $\begin{array}{c}1.3 q: 1 \AA \\
(\chi 2=56.34 ; \mathrm{df}=1, \mathrm{P}<0.001)\end{array}$ & $\begin{array}{c}7 \text { + }: 1 \delta \\
(\chi 2=52 ; \mathrm{df}=1, \mathrm{P}<0.001)\end{array}$ & $\begin{array}{c}2.8+9: 1 \AA \\
(\chi 2=25.78 ; \mathrm{df}=1, \mathrm{P}<0.001)\end{array}$ \\
\hline 2006 & $\begin{array}{c}0.7 \stackrel{+}{ }: 10 \\
(\chi 2=11.08 ; \mathrm{df}=1, \mathrm{P}<0.001)\end{array}$ & $\begin{array}{c}7.8 \text { 古: } 1 \text { 万 } \\
(\chi 2=49.54 ; \mathrm{df}=1, \mathrm{P}<0.001)\end{array}$ & $\begin{array}{c}1.1 \text { 里 } 1 \text { 万 } \\
(\chi 2=40.5 ; \mathrm{df}=1, \mathrm{P}<0.001)\end{array}$ \\
\hline 2007 & $\begin{array}{c}1.3 \text { 古: } 1 \text { 今 } \\
\left(\chi^{2}=433.94 ; \mathrm{df}=1, \mathrm{P}<0.001\right)\end{array}$ & $\begin{array}{c}5.8+9: 1 \text { त } \\
(\chi 2=137.36 ; \mathrm{df}=1, \mathrm{P}<0.001)\end{array}$ & $\begin{array}{c}1.9+10 \\
(\chi 2=1464.74 ; \mathrm{df}=1, \mathrm{P}<0.001)\end{array}$ \\
\hline
\end{tabular}

*no data available. 
these wasps took approximately two months to complete their juvenile stage during direct development and used this value to estimate the number of generations during the year.

During 2002, 2003, 2005 and 2006, the adults emerged from diapause and began to nest in September. From September of these years through January of the following, all of the descendants of these wasps showed direct development, with two generations per year (Figure 3). In these period, the adults emerging in October had first-generation descendants emerging in December and second-generation descendants emerging in February. The individuals that left diapause in November and December each produced only one generation that emerged in January and February, respectively.

In 2004, the adults also emerged from diapause in September. However, the wasps showed direct development until April, with three generations during this year (Figure 3). Individuals of the first, second and third generations emerged in November, January and March, respectively. For the wasps that left diapause in October, the first generation emerged in December, the second in February and the third in April. Those that emerged only in November and December had only two generations.

In contrast, in 2007, T. agamemnon began to nest in August and had three generations during the year because the wasps exhibited direct development until January 2008 (Figure 3).

\subsection{Adult weight and amount of provisions}

Six hundred and one adults were weighed, including 169 males and 432 females (Table 3). The weights of the males that emerged from the 5- and 7-mm nests did not differ significantly. The females that emerged from the 7-mm nests were significantly heavier than those that emerged from the 5-mm nests (Kruskal-Wallis $H=190.7675$, df= 3, $\mathrm{p}<0.05)$. Females were significantly heavier than males, both among individuals from nests with different diameters and in nests of the same diameter (Kruskal-Wallis $H=$ 361.6987, $\mathrm{df}=5, \mathrm{p}<0.05)$.

The amount of food provisioned for females was significantly greater than for males (Mann-Whitney, $U=280.5, \mathrm{p}=0.0000)($ Table 3$)$.

Table 2. The average number of days of direct and delayed development of juveniles of T. agamemnon in 2002, 2003, 2004, 2005,2006 and 2007.

\begin{tabular}{ccc}
\hline & DIRECT DEVELOPMENT & DELAYED DEVELOPMENT \\
\hline \multirow{2}{*}{2002} & $52.4 \pm 6.4$ & $222.3 \pm 43.9$ \\
& $\mathrm{n}=24$ & $\mathrm{n}=41$ \\
$\mathbf{2 0 0 3}$ & $63.7 \pm 6.8$ & $239.8 \pm 40.8$ \\
$\mathbf{2 0 0 4}$ & $\mathrm{n}=31$ & $\mathrm{n}=32$ \\
& $61.4 \pm 9$ & $235.7 \pm 58.3$ \\
$\mathbf{2 0 0 5}$ & $\mathrm{n}=14$ & $\mathrm{n}=47$ \\
$\mathbf{2 0 0 6}$ & $50 \pm 11.2$ & $221 \pm 48.6$ \\
& $\mathrm{n}=14$ & $\mathrm{n}=24$ \\
$\mathbf{2 0 0 7}$ & $51.4 \pm 12.1$ & $216.4 \pm 46.9$ \\
& $\mathrm{n}=55$ & $\mathrm{n}=39$ \\
& $58.2 \pm 18.6$ & $176.8 \pm 47.2$ \\
\end{tabular}

Values are means $\pm \mathrm{SD}$, with sample size indicated.

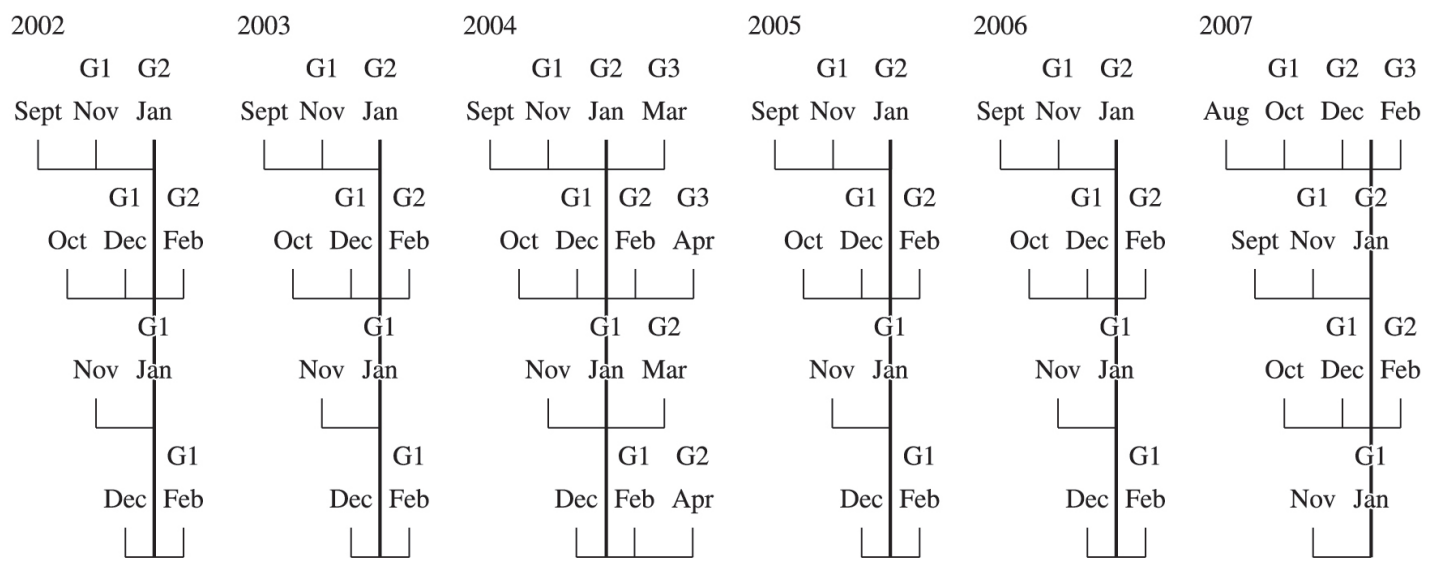

Figure 3. The number of generations during 2002, 2003, 2004, 2005, 2006 and 2007 and the amount of overlap between T. agamemnon adults. 
Table 3. Adults weights ( $\mathrm{g}$ ) of $T$. agamemnon from two different trap-nests diameters and the weights (mg) of spiders consumed by them.

\begin{tabular}{ccc}
\hline & ADULT WEIGHTS & SPIDERS WEIGHTS \\
\hline \multirow{3}{*}{ Female } & $0.0325 \pm 0.0072$ & $0.1403 \pm 0.0327$ \\
& median $=0.0330$ & median $=0.1411$ \\
$\mathrm{n}=432$ & $\mathrm{n}=61$ \\
Male & $0.0242 \pm 0.0114$ & $0.1074 \pm 0.0241$ \\
& median $=0.0235$ & median $=0.1037$ \\
$\mathrm{n}=169$ & $\mathrm{n}=24$ \\
\hline
\end{tabular}

Values are means $\pm \mathrm{SD}$, with sample size indicated.

\section{Discussion}

We collected data on the life history and sex ratio of the mass-provisioning solitary wasp T. agamemnon. This species is bivoltine or multivoltine, with until three generations per year. It has two alternative life histories (diapause and direct development) and overlapping generations. Similar results have been recorded for other Trypoxylon species in tropical and subtropical regions (Camillo et al., 1993, 1994; Buschini et al., 2006; Buschini and Wolff, 2006; Buschini, 2007; Buschini and Bergamaschi, 2010). Temperate species of Trypoxylon have life histories similar to those of subtropical and tropical species, but only a generation or a second partial generation has been recorded for temperate species, i.e. they are univoltine or partially bivoltine (Coville, 1982; Krombein, 1967; Brockmann and Grafen, 1989, 1992; Brockmann, 2004).

In T. agamemnon, the sex ratios were strongly and consistently female-biased. T. agamemnon had a heavily female-biased sex ratio compared with those of Trypoxylon lactitarse Saussure, 1867 (Buschini, 2007) and Trypoxylon opacum Brèthes, 1913 (Buschini and Bergamaschi, 2010) species which also occur in the study area. In T. lactitarse, the sex ratio was $1: 1$. The most generally accepted explanation of a 1:1 sex ratio is Fisher's (1930) notion that the cost for the production of males and females is equal. According to Fisher (1958), the sex ratio is female-biased only if females are smaller than males. The sex ratio in T. agamemnon is strongly female-biased, but the females are significantly larger than the males. This finding indicates that the mothers invested preferentially in the production of female offspring for several consecutive years.

One hypothesis cited by Boomsma (1989) and Helms (1994) to explain a female-biased sex ratio in the Hymenoptera is "local mate competition", proposed by Hamilton (1967). According to him, Fisher's idea of equal investment in males and females no longer holds if there is local competition between brothers for mates (local competition for mates). If a mother "knows" that her daughters will all be fertilized by her sons, she should primarily produce daughters, and sons should only be produced in sufficient numbers to fertilize the females.

In a study of the life history and sex allocation of T. opacum, Buschini and Bergamaschi (2010) discuss all these proposals and conclude that species of Trypoxylon exhibit patterns of life history and sex allocation much more complex than previously imagined. For example, in several species of the subgenus Trypargilum the males perform nest guarding, a behavior pattern uncommon in Hymenoptera. The mothers benefit greatly from male nest-guarding because it allows them to spend more time foraging. The benefit of nest-guarding to males is that they mate with the female just prior to oviposition. However, because Hymenoptera are haplodiploid and the males are fatherless, the male will be the father only of the female offspring. Apparently, the mother wasps "agree" to produce daughters so that males will guard their nests (Brockmann and Grafen, 1992). The sex ratio in T. opacum also tends to be female-biased and Buschini and Bergamaschi (2010) considered that the mothers in this species would benefit highly from producing sons because the expected fitness of the sons is much higher than the expected fitness of the daughters. However, the male guarding a mother's nest gets no benefit from her sons, regardless of the sex ratio these authors consider that this situation represents a case of inherent genetic conflict between mates. It is very interesting that in this sense, the outcome seems to favor the interests of the male. Of course, it is possible that the mother could lay more male-destined eggs, but apparently the cost of doing so would be abandonment by the guarding male.

In T. agamemnon, the males not only guard the nests but also receive the spiders brought by females. The female does not provision the cell unless a male is present. If she arrives and the male is not present, she begins discarding all the provisioned spiders (Buschini and Donatti, 2012). Although parental care is rare in some wasps, it is commonly observed in Trypoxylon, in which the males participate in activities in addition to nest-guarding (Coville and Coville, 1980; Brockmann and Grafen, 1989). According to Coville and Coville (1980), help of this kind from the male allows the female to devote more time to foraging and to accumulate more prey in each cell. In species of Trypoxylon (Trypargilum), the females are larger than the males and are produced in cells with larger quantities of food (Molumby, 1997; Peruquetti and Del Lama, 2003). This observation suggests that sexual dimorphism in size could facilitate the evolution of guarding and helping behaviors at the nests of Trypargilum species. The male would "help" his partner better provision the cells to produce female progeny and thus benefit from helping. 
Another hypothesis suggested by Buschini and Bergamaschi (2010) to explain the strongly femalebiased sex ratio in T. opacum is that males live longer than females, and the sex ratio is therefore balanced in the field (1:1). However, Buschini and Donatti (2012) observed that both males and females in T. agamemnon are relatively long-lived, with a lifespan of over a year.

The hypothesis of "split sex ratios" (Grafen, 1986) was the second possible explanation for the presence of males in the female-biased population of T. opacum (Buschini and Bergamaschi, 2010). This hypothesis suggests that females were produced in the trap-nests that were under observation, whereas the males were produced elsewhere. We hypothesize that this also occurs in T. agamemnon. A surplus of males always seems to occur in the area. In addition to the male that guards each nest that is being built, satellite males often circle the area and mate with the females when the females return with spiders from the field. However, Buschini and Donatti (2012) observed that after the construction of the nest is completed, the female does not always remain with the same male. Satellite males frequently assume the role of nest-guarding, and the males that were guarding the nest assume the role of satellite males. Therefore, the hypothesis of split sex ratios does not make sense for T. agamemnon. Rather, local mate competition is occurring among male T. agamemnon in this area and results in a greater investment in the production of females.

Our data on T. agamemnon are consistent with some ideas in sex allocation theory and allow other hypotheses to be rejected. In addition to a conflict of interest between the sexes, it is possible that local mate competition is occurring between males and favoring a greater investment in the production of females. According to Brockmann and Grafen (1992), the differences among life histories in Trypoxylon are related to differences in phenology and hunting conditions. These differences affect cost ratios, female investment and sex allocation patterns. Further studies should focus on these factors and should use molecular analysis to assess the degree of genetic relatedness between males, guards and satellites, and the offspring inside the nests.

Acknowledgements - Partial financial support was provided by Fundação Araucária (The State of Paraná Research Foundation) and UNICENTRO (Guarapuava - PR, Brazil). We also thank Prof. Dr. Sérvio Túlio Amarante from the Museu de Zoologia da USP (SP, Brazil) for identifying the wasp.

\section{References}

AYRES, M., AYRES, JRM., AYRES, DL., and SANTOS, AS., 2003. BioEstat 3.0. Aplicações estatísticas nas áreas das ciências biológicas e médicas. Belém: Sociedade Civil de Mamirauá.

BOOMSMA, JJ., 1989. Sex-investment ratios in ants: has female bias been systematically overestimated? American Naturalist, vol. 133, no. 4, p. 517-532. http://dx.doi.org/10.1086/284933
BROCKELMAN, WY., 1975. Competition, the fitness of offspring and optimal clutch size. American Naturalist, vol. 109, no. 970, p. 677-699. http://dx.doi.org/10.1086/283037

BROCKMANN, HJ., 2004. Variable life-history and emergence patterns of the pipe-organ mud-daubing wasp, Trypoxylon politum (Hymenoptera: Sphecidae). Journal of the Kansas Entomological Society, vol. 77, no. 4, p. 503-527. http://dx.doi.org/10.2317/E43.1

BROCKMANN, HJ. and GRAFEN, A., 1989. Mate conflict and male behavior in a solitary wasp, Trypoxylon (Trypargilum) politum (Hymenoptera: Sphecidae). Animal Behaviour, vol. 37, no. 2, p. 232-255.

-, 1992. Sex ratios and life-history patterns of a solitary wasp, Trypoxylon (Trypargilum) politum (Hymenoptera: Sphecidae). Behavioral Ecology and Sociobiology, vol. 30, no. 1, p. 7-27.

BUSCHINI, MLT., 2006. Species diversity and community structure in trap-nesting bees in Southern Brazil. Apidologie, vol. 37, p. 58-66. http://dx.doi.org/10.1051/apido:2005059

-, 2007. Life-history and sex allocation in Trypoxylon (syn. Trypargilum) lactitarse (Hymenoptera; Crabronidae). Journal of Zoological Systematics and Evolutionary Research, vol. 45, no. 3 , p. $206: 213$.

BUSCHINI, MLT. and WOLFF, LL., 2006. Notes on the biology of Trypoxylon (Trypargilum) opacum Brèthes (Hymenoptera; Crabronidae) in southern Brazil. Brazilian Journal of Biology, vol. 66, no. 3, p. 907-917. PMid:17119839. http://dx.doi.org/10.1590/ S1519-69842006000500017

BUSCHINI, MLT. and BERGAMASCHI, ACB., 2010. Strongly female-biased sex allocation in a trivoltine population of Trypoxylon (Trypargilum) opacum Brèthes (Hymenoptera, Crabronidae). Acta Zoologica, vol. 91, no. 4, p. 433-439. http://dx.doi.org/10.1111/ j.1463-6395.2009.00430.x

BUSCHINI, MLT. and FAJARDO, S., 2010. Biology of the solitary wasp Trypoxylon (Trypargilum) agamemnon Richards 1934 (Hymenoptera: Crabronidae) in trap-nests. Acta Zoologica, vol. 91 , no. 4, p. 426-432. http://dx.doi.org/10.1111/j.14636395.2009.00429.x

BUSCHINI, MLT. and DONATTI, AJ., 2012. Nesting behavior of Trypoxylon (Trypargilum) agamemnon Richards (Hymenoptera: Crabronidae). Brazilian Journal of Biology, vol. 72, no. 2, p. 353-362. PMid:22735144. http://dx.doi.org/10.1590/S151969842012000200017

BUSCHINI, MLT., NIESING, F. and WOLFF, LL., 2006. Nesting biology of Trypoxylon (Trypargilum) lactitarse Saussure (Hymenoptera; Crabronidae) in trap-nests in southern Brazil. Brazilian Journal of Biolology, vol. 66, no. 3, p. 919-929. PMid:17119840. http://dx.doi.org/10.1590/S1519-69842006000500018

CAMILLO, E., GARÓFALO, CA. and SERRANO, JC., 1994. Observações sobre a biologia de Trypoxylon (Trypargilum) rogenhoferi Kohl (Hymenoptera: Sphecidae). Anais da Sociedade Entomológica do Brasil, vol. 23, no. 2, p. 299-310.

CAMILLO, EC., GARÓFALO, CA., MUCCILIO, G. and SERRANO, JC., 1993. Biological observation on Trypoxylon (Trypargilum) lactitarse Saussure in Southeastern Brazil (Hymenoptera, Sphecidae). Revista Brassileira de Entomologia, vol. 37 , no. 4 , p. $769-778$

CHARNOV, EL., 1979. The genetical evolution of patterns of sexuality: Darwinian fitness. American Naturalist, vol. 113, no. 4, p. 465-480. http://dx.doi.org/10.1086/283407 
-, 1982. The theory of sex allocation. New Jersey: Princeton University Press.

COVILLE, RE., 1982. Wasps of the Genus Trypoxylon Subgenus Trypargilum in North America (Hymenoptera: Sphecidae). Berkeley: The University of California Press.

COVILLE, RE. and COVILLE, PL., 1980. Nesting biology and male behavior of Trypargilum tecnoctitlan in Costa Rica (Hymenoptera: Sphecidae). Annals of the Entomological Society of America, vol. 73, no. 1, p. 110-119.

COWAN, DP., 1981. Parental Investment in Two Solitary Wasps Ancistrocerus adiabatus and Euodynerus foraminatus (Eumenidae: Hymenoptera). Behavioral Ecology and Sociobiology, vol. 9, no. 2, p. 95-102. http://dx.doi.org/10.1007/BF00293580

FISHER, RA., 1930. The genetical theory of natural selection. Oxford: Oxford University Press.

-, 1958. The genetical theory of natural selection. New York: Dover Publications.

FLANDERS, SE., 1965. On die sexuality and sex ratios of hymenopterous populations. American Naturalist, vol. 93, p. 489-494.

FROHLICH, DR. and TEPEDINO, VJ., 1986. Sex ratio, parental investment and interparent variability in nesting success in a solitary bee. Evolution, vol. 40, p. 142-151. http://dx.doi. org/10.2307/2408611

GRAFEN, A., 1986. Split sex ratios and the evolutionary origins of eusociality. Journal of Theoretical Biology, vol. 122, no. 1, p. $95-121$. http://dx.doi.org/10.1016/S0022-5193(86)80227-2
Guarapuava. Prefeitura Municipal. Secretaria de Meio Ambiente e Desenvolvimento Florestal - SEMAFLOR. Available from: $<$ www.prefeituramunicipaldeguarapuava $>$. Access in: 4 Apr 2012.

HAMILTON, WD., 1967. Extraordinary sex ratio. Science, vol. 156, no. 3774, p. 477-488. PMid:6021675. http://dx.doi. org/10.1126/science.156.3774.477

HELMS, KR., 1994. Sexual size dimorphism and sex ratios in bees and wasps. American Naturalist, vol. 143, no. 3, p. 418-434. http://dx.doi.org/10.1086/285611

KREBS, CJ., 1989. Ecological methodology. New York: Harper e Row.

KROMBEIN, KV., 1967. Trap-Nesting Wasps and Bees: Life Histories, Nests and Associates. Washington: Smithsonian Press.

LIN, N., 1979. Differential prey selection for the sex of offspring in the cicada killer Sphecius spheciosus (Hymenoptera: Sphecidae). Proceedings of the Entomological Society of Washington, vol. 81 , no. 2, p. 269-275.

MOLUMBY, A., 1997. Why make daughter larger? Maternal sex allocation and sex-dependent selection for body size in a massprosioning wasp, Trypoxylon politum. Behavioral Ecology, vol. 8, no. 3, p. 279-287. http://dx.doi.org/10.1093/beheco/8.3.279

PERUQUETTI, RC. and DEL LAMA, MA., 2003. Alocação sexual e seleção sexo-dependente para tamanho de corpo em Trypoxylon rogenhoferi Kohl (Hymenoptera, Sphecidae). Revista Brasileira de Entomologia, vol. 47, no. 4, p. 581- 588. http:// dx.doi.org/10.1590/S0085-56262003000400008

PIANKA, ER., 1976. Natural selection of optimal reproductives tactics. American Zoologist, vol. 16, p. 775-784. 